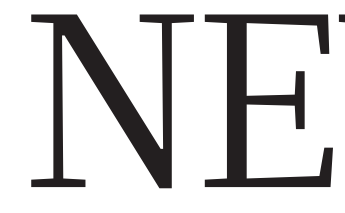

ENVIRONMENT Oil-spill researchers wrangle over chemical remedy $\mathbf{p . 4 6 1}$
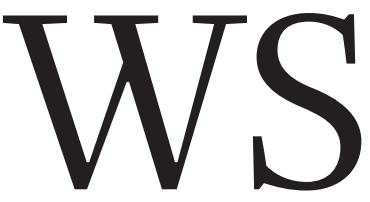

ASTRONOMY Masking a telescope so it can see an exo-Earth p.464
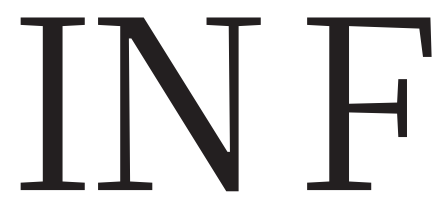

JAPAN Economic

stimulus bets big on stem

cells, space and materials p.465
Ce

\begin{abstract}
NEUROSCIENCE Fish
swimming in virtual world

illuminate the brain $\mathbf{p . 4 6 6}$
\end{abstract}

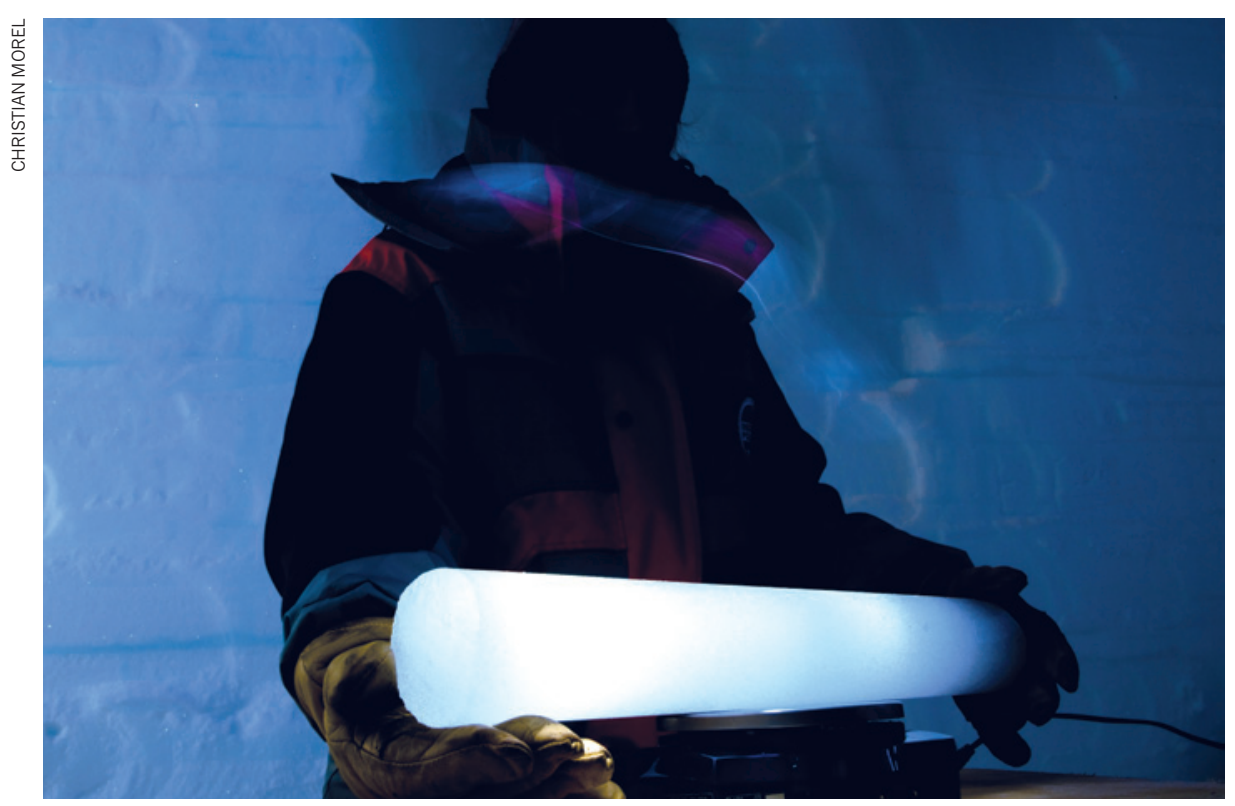

Isotopes in this ice core reveal how glaciers responded to climate change more than 100,000 years ago.

CLIMATOLOGY

\title{
Greenland defied ancient warming
}

But Antarctic glaciers may be more vulnerable than thought.

\section{BY QUIRIN SCHIERMEIER}

$\mathrm{O}$ ver a few exceptionally warm days last July, Greenland's frozen surface turned into a colossal puddle. Even the coldest parts of the world's largest island saw ice thaw and rain fall, fuelling concerns over the future of glaciers that hold enough water to raise global sea levels by around 7 metres.

A record of the past written in an ancient ice core now reveals that Greenland's ice sheet is not melted as easily as some fear. But the message is not entirely reassuring: it also implies that Antarctica has much greater potential to raise sea levels than previously thought.

The 2,540-metre-long core comes from a site in northwestern Greenland that hosts some of the island's oldest ice, dating back to the Eemian interglacial: the Earth's most recent warm period before temperate conditions returned once more some 12,000 years ago. Lasting from about 130,000 to 115,000 years ago, the Eemian warming was triggered by increases in summer sunshine, resulting from variations in Earth's orbit and axis of rotation. But it may be a good model of the man-made climate change expected over the coming centuries. "We are in a similar climate regime as the world was in the early Eemian," says Eric Steig, who studies ice cores at the University of Washington in Seattle.

The North Greenland Eemian Ice Drilling (NEEM) project, a 14-nation research team, has spent the past four years drilling and analysing the core, and its results are published in Nature this week ${ }^{1}$. Extracting a record of the Eemian was a challenge: the core's lowest layers

had been deformed and folded by the constant movement of the ice sheet. "Of course we had hoped for a purer record," says Dorthe DahlJensen, a palaeoclimatologist at the University of Copenhagen who led the NEEM project. "But it is a fantastic record even so, and it does have all the information we needed to reliably reconstruct the Eemian climate and ice-sheet history."

She and her colleagues painstakingly compared and synchronized the disturbed parts of their core, layer by layer, with other welldated ice cores from Greenland and Antarctica to tease out the story. "I am very sure that we have got the picture right," says Dahl-Jensen.

The results confirm the warmth of the Eemian climate: ratios of oxygen and nitrogen isotopes in the core show that some 6,000 years after the onset of the Eemian, local temperatures reached about $8^{\circ} \mathrm{C}$ above the present-day annual average of roughly $-25^{\circ} \mathrm{C}$.

But the ice sheet at the NEEM site did not get much thinner than its present 2.5 kilometres, according to the air content in the core that the team correlated with elevation. Before the Eemian, the Greenland ice sheet was some 200 metres thicker than it is today, and after six millennia of strong warming the ice sheet lost just over one-tenth of its thickness, dropping to 130 metres below its present height. It then remained steady until the end of the Eemian (see 'Warm spell'). "It's illuminating to see just how strongly Greenland had warmed at the time," says Steig. "That the warming seemingly caused only relatively modest melting is of course also remarkable."

There is a small possibility that the reconstruction is incomplete because it reflects conditions at only one site, which may provoke debate about the results, says Steig. Until the past few years, most researchers had thought that Greenland contributed at least half of the 6-8 metres of Eemian sea-level rise that has been deduced from records of ancient corals and other markers ${ }^{2}$. Yet the NEEM core implies that Greenland's ice sheet lost at most one-quarter of its volume, and contributed no more than 2 metres of sea-level rise. "The good news is that Greenland is not as sensitive to climate warming as we thought," says Dahl-Jensen.

DNATURE.COM Read more about the melting Arctic in Nature's special at. go.nature.com/s5w2pr
"The bad news is that if Greenland's ice sheet did not disappear during the Eemian, Antarctica must have been responsible for a significant part 
of the sea-level rise," she adds. These two ice sheets, the world's biggest, have been stable for most of the current interglacial period. But since temperatures began to soar a couple of decades ago, Greenland and Antarctica have been shedding ice fast. Between 1992 and 2011, they lost around 2,700 billion and 1,350 billion tonnes of ice, respectively - enough to raise sea levels by about 0.6 millimetres per year ${ }^{3}$. Scientists think that by 2100 , the global sea level may have risen by $0.5-1.2$ metres above current levels.

Although ice loss is currently greatest in Greenland, that could change: some parts of Antarctica are warming almost twice as fast as previously believed ${ }^{4}$, and glaciers in western Antarctica have retreated at a worrying rate in the past few decades ${ }^{5}$. Furthermore, Eemian sea-level rise seems to have proceeded in drastic jumps, rather than gradually ${ }^{6}$, suggesting that the ongoing sea-level rise could accelerate.

That may not be a menace to civilization yet. But, says Dahl-Jensen, if Antarctica's massive ice sheets do disintegrate - as the NEEM core suggests they did before - we could face an extremely rapid sea-level rise around the world. NEEM's message is that the Eemian is distant only in years, not in consequence.

1. NEEM community members Nature $\mathbf{4 9 3}, 489-494$ (2013).

2. Cuffey, K. M. \& Marshall, S. J. Nature 404, 591-594 (2000).

3. Shepherd, A. et al. Science 338, 1183-1189 (2012).

4. Bromwich, D. H. et al. Nature Geosci. http://dx.doi. org/10.1038/ngeo1671 (2012).

5. Hillenbrand, C.-D. et al. Geology 41, 35-38 (2013).

6. Blanchon, P., Eisenhauer, A., Fietzke J. \&

Liebetrau, V. Nature 458, 881-884 (2009).

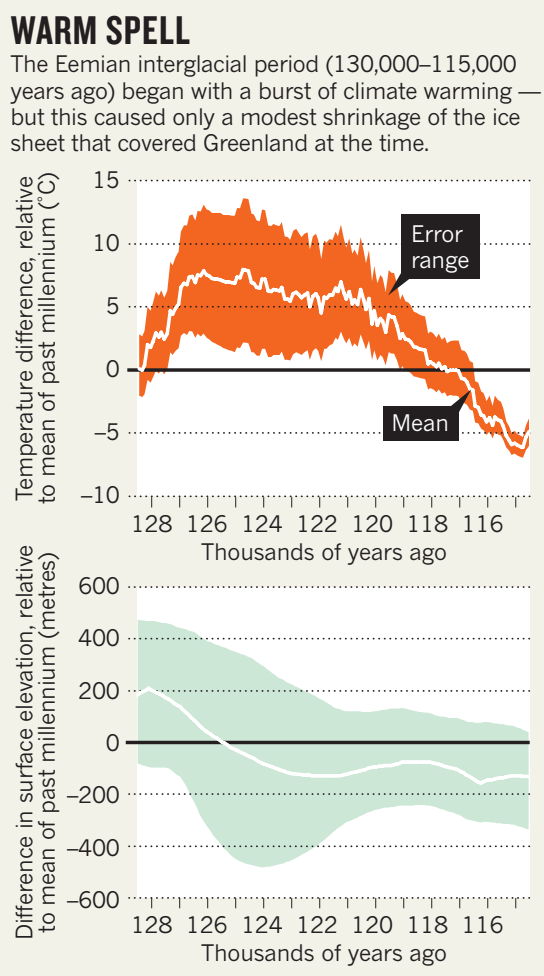

\section{Work resumes on lethal flu strains}

\section{Study of lab-made viruses a 'public-health responsibility'.}

\section{BY DECLAN BUTLER}

A $\mathrm{n}$ international group of scientists this week ended a year-long moratorium on controversial work to engineer potentially deadly strains of the H5N1 avian flu virus in the lab.

Researchers agreed to temporarily halt the work in January 2012, after a fierce row erupted over whether it was safe to publish two papers reporting that the introduction of a handful of mutations enabled the $\mathrm{H} 5 \mathrm{~N} 1$ virus to spread efficiently between ferrets, a model of flu in mammals (see Nature http://doi.org/ fxv55r; 2012). Both papers were eventually published, one in Nature ${ }^{1}$ and one in Science ${ }^{2}$.

Now, in a letter simultaneously published on 23 January by Nature 3 and Science, the 40 scientists involved say that the moratorium has served its purpose: allowing time for authorities to review the conditions under which the research could be safely conducted and for scientists to explain the public-health benefits of the work. Scientists who now have official approval in their countries to conduct such research "have a public-health responsibility to resume this important work", the letter states, "because the risk exists in nature that an $\mathrm{H} 5 \mathrm{~N} 1$ virus capable of transmission in mammals may emerge".

The move follows a large international workshop convened on 17-18 December by the US National Institutes of Health in Bethesda, Maryland, to discuss 'gain-of-function research' - that intended to increase the transmissibility, host range or virulence - in $\mathrm{H} 5 \mathrm{~N} 1$ viruses, and the development of US rules for stricter oversight of research in this area. The proposed rules require an assessment of, for example, whether the scientific aims of such studies could be addressed using alternative, less-risky approaches, and whether biosafety and biosecurity risks can be adequately mitigated. They are expected to enter into force soon, allowing scientists working in the United States or on US-funded grants to restart such research.

The groups that published the original research have outlined a suite of possible follow-up experiments, including a search for other combinations of mutations that would allow $\mathrm{H} 5 \mathrm{~N} 1$ to transmit between mammals - which could answer basic-science questions and, they argue, aid efforts to watch for dangerous mutations in the wild. The researchers also suggest extending the studies in ferrets to other mammals, such as guinea pigs, because further evidence of transmission within mammalian species would increase confidence that the mutated virus would transmit between humans.

But the scientific community remains divided on whether the practical benefits of the research outweigh the risks of an accidental or deliberate release of a lab-created flu strain. Ian Lipkin, a specialist on emerging infectious diseases at Columbia University in New York, believes that the risks are high and, worse, that such research may end up being done in labs with insufficient biosafety standards.

The World Health Organization (WHO) posted general biosafety guidelines for such work on its website last July (go.nature. com/4z4yzg), but Lipkin says such guidelines need to be extended and given more teeth before work restarts. He suggests that this could be done by including them in the WHO's international legally binding treaty on global threats to health - the 2005 International Health Regulations. Ron Fouchier at Erasmus Medical Centre in Rotterdam, the Netherlands, who led the research behind last year's Science paper, disagrees. He says that national and institutional procedures have long proved adequate. "If we have to wait until all national governments in the world agree on terms and conditions, we can wait for years if not forever," he says. "That is unacceptable."

But even some who support the lifting of the moratorium have misgivings about the future. Ilaria Capua, a flu researcher at the Veterinary Public Health Institute in Legnaro, Italy, who signed the letter, says that she is less concerned about current work, which is limited to a handful of labs with high biosafety standards, than about the risk of proliferation of such research in the longer term. "This is not a decision for scientists," she says, "it's a decision for policy-makers; do we want to continue to invest public funds in this type of work?"= SEE EDITORIAL P.251

\footnotetext{
1. Imai, M. et al. Nature 486, 420-428 (2012).

2. Herfst, S. et al. Science 336, 1534-1541 (2012).

3. Fouchier, R. A. M. et al. Nature http://dx.doi. org/10.1038/nature11858 (2013).
} 